\title{
M. Salmasizadeh
}

University Of Tabriz, Tabriz, Iran

e-mail: msalmasizadeh@tabrizu.ac.ir

\section{Russian-Turkish war 1877-1878 in Iranian historiography of the XIX century and modern Iranian historiography}

\begin{abstract}
The conflict between the Russian and Turkish in 1877-1878, though formed on the pretext of Russia's support for Christian nations under the rule of the Ottoman Empire, was actually part of the great scheme that European governments had begun to break up the Ottoman Empire and resolve the Eastern Question. The goals of these powers for world domination, that would sometimes results in wars among themselves, were mainly focused on expanding the territorial realm and winning economic gains. These goals were followed under the disguise of gaining freedom for Christians and securing independence for non-Turkish nations. The scientific and technological impairment of the Ottoman Empire compared to the European countries, accompanied by internal rivalries and frequent overthrow of the rulers, were some of the main weaknesses of the Ottoman state causing their demise. In the meantime, Russia was in pursue of its policy of territorial expansion and seeking access to warm waters. Russia's main objective was to obtain access to the Black Sea and the Mediterranean Sea. Having control over the Straits of Bosporus and Dardanelles that were under the rule of the Ottoman Empire would have connected Russia to the center of world trade in the Mediterranean and would have freed Russia from its land blockages and frozen ports. The causality, the start, and the ramifications of these wars have been reflected in the Iranian historiography of that era. Mohammad Hassan Khan Etemad al-Saltanah, a great historian of the Nasereddin Shah Qajar Age (1848-1898), using the reports of Iranian officials in Russia and the Ottoman Empire, and two books of Montazame Nasseri and Merat al-Boldan that were translations of selected articles from the French and Ottoman newspapers have recorded this important historical event. The reasons for Iranian attention to this historical event forms part of the modern and global historiography of Iran, in which attention to the developments in the Ottoman Empire plays an important role in Iran's acquaintance with modern civilization.
\end{abstract}

Key words: Russian, Ottoman Empire, Treaty of San Stefano, Berlin Congress

For citation: Salmasizadeh M. Russian-Turkish war 1877-1878 in Iranian historiography of the XIX century and modern Iranian historiography // History and modern perspectives. 2020. Vol. 2. №1. P. 56-61.

\section{М. Салмасизаде}

Университет Тебриза, г. Тебриз, Иран

e-mail: msalmasizadeh@tabrizu.ac.ir

\section{Русско-турецкая война 1877-1878 гг. в иранской историо- графии XIX в. и в современной иранской историографии}

Аннотация. Конфликт между Россией и Турцией в 1877-1878 гг. возник под предлогом поддержки Россией христианских наций, находившихся под властью Османской империи, но фактически был частью глобальной схемы, согласно которой европейские правительства разрушали Османскую империю и занимались решением «Восточного вопроса». Цели европейских держав были в основном направлены на расширение территориальной сферы их влияния и получение экономических выгод. Этому способствовала технологическая слабость Османской империи.

Основная цель России состояла в том, чтобы получить доступ к Средиземному морю. Контроль над проливами Босфор и Дарданеллы, которые находились под властью Османской империи, связал бы Россию с центром мировой торговли в Средиземном море. Причины, начало и последствия этих войн были отражены в иранской историографии той эпохи. Особое внимание этим проблемам уделил Мохаммад Хасан Хан, Этемад аль-Салтана, крупнейший историк эпохи Насреддин-Шаха из династии Каджаров (1848-1898).Автор показывает, что внимание иранских историков к этим сюжетам обусловлено интересом к тем процессам, которые протекали в Европе, поскольку они оказывали влияние на состояние глобальной политической системы.

Ключевые слова: Российская империя, Османская империя, Восточный вопрос, Сан-Стефанский договор, Берлинский Конгресс.

Для цитирования: М. Салмасизаде Русско-турецкая война 1877-1878 гг. в иранской историографии XIX в. и в современной иранской историографии // История и современное мировоззрение. 2020. Т. 2. №1. С. 56-61. 


\section{INTRODUCTION}

The conflict between the Russian and Ottoman governments in 1877-1878, though formed on the pretext of Russia's support for Christian nations under the rule of the Ottoman Empire, was actually part of the great scheme that European governments had begun to break up the Ottoman Empire and resolve the Eastern Question. The goals of these powers for world domination, that would sometimes results in wars among themselves, were mainly focused on expanding the territorial realm and winning economic gains. These goals were followed under the disguise of gaining freedom for Christians and securing independence for non-Turkish nations.

In the meantime, Russia was in pursue of its policy of territorial expansion and seeking access to warm waters. Russia's main objective was to obtain access to the Black Sea and the Mediterranean Sea. Having control over the Straits of Bosporus and Dardanelles that were under the rule of the Ottoman Empire. The Straits could have connected Russia to the center of world trade in the Mediterranean and would have freed Russia from its land blockages and frozen ports.

The causality, the start, and the ramifications of these wars have been reflected in the Iranian historiography of that era. Mohammad Hassan Khan Etemad Al-Saltanah, a great historian of the Nasereddin shah Qajar Age (1848-1898), using the reports of Iranian officials in Russia and the Ottoman Empire, and two books of Montazame Nasseri's History and Merat al-Boldan that were translations of selected articles from the French and Ottoman newspapers have recorded this important historical event. The reasons for Iranian attention to this historical event forms part of the modern and global historiography of Iran, in which attention to the developments in the Ottoman Empire plays an important role in Iran's acquaintance with modern civilization.

\section{AN OVERVIEW OF ETEMAD AL-SALTANAH AND HIS TWO HISTORICAL BOOKS}

He was the political and cultural rector of Iran during the Nasereddin shah Qajar Age (1848-1898), which was entrusted to the Ministry of Public Affairs. He was the trustee of the Nasereddin shah Qajar (1848-1896) and was responsible for the committee to translate and compile historically valuable books.A prolific and interested man who was able to publish 37 books. He has a huge right on the neck of Iranian history and culture. Etemad al-Saltanah was one of the first Darulfonon students and the first Iranian studens that studied in Europe in 1863. Four years in France, he became fluent in this language and became familiar with scientific research. On returning to Iran (in 1867), as a translator and responsible for Darottebae (the royal publishing center) and a newspaper officer at the court of Nasereddin shah Qajar, he was minister of culture and education until the end of his life (in 1896). Two newspapers were published by him: Iran and Merrikh.He founded a school for teaching new sciences and European languages (Called Moshiryeh School). He was the official interpreter of Shah in his travels to Europe and when the Shah met with foreign ambassadors, he was the official interpreter. In 1887 he was named Etemad alSaltanah which showed that it was trusted by the Shah and the government.

He used for the first time in Iranian historiography a criticalscientific method. Both books of 'Merat al-Boldanand' the 'Montazame Nasseri's History' have been written in the same way and their data is scientific. The three-volume book of 'Montazame Nasseri's History' and the four-volume book of 'Merat alBoldanand' is an example of his historical works 'Merat alBoldanand' was originally written for descriptions of the cities and villages of the Iran, but from the second volume Describes the first thirty years (1848-1878) of the Nasereddin shah Qajar monarchy. Precisely For this reason, the book is considered to be a first-time source for recording historical information related to the Berlin conference and the historical-geographical description of the Qotur region.

But the book of 'Montazame Nasseri's History', written between 1881 and 1883 and presented to the Shah, conveyed the universal history of the world from the emigration of the Islam Prophet to the Dynasty of Qajar (1798-1925). The author has set his historical reports based on the geographic sections of the world (Asia, Europe, Africa and the American continent), and It is unique in this regard. The author wrote this book using historical sources by chronological method, and donated it to Nasereddin shah Qajar. In this book, there is information from the Safavid (1501-1722) era to the life of the author about the subject matter of this study.

As it was said, Etemad al-Saltanah has been using official diplomatic reports and newspapers as a compilation of reports on the Berlin Congress and describing its 64 articles. The official text of the Berlin Congress declaration was written by translation from the French and Turkish languages which was published in newspapers.

He was also aware of the content of the reports that the Ambassador of Iran sent from France, and it was reflected in his writings. These reports were from two sources, one of the meetings of the Iranian ambassador to Paris with the Russian and Ottoman ambassadors and others The countries involved in the conflict, such as the United Kingdom, Germany and Prussia, as well as other news stories from the major newspapers of the "European Diplomacy" and "Memorial", in these reports, Russia has become a definitive defeat of the absolute and Ottoman conquerors. The Iranian ambassador to France introduces Russia's victory in the power of the country's military and the tacit accompaniment of a new and strong German government to Russia, and an important obstacle to the certainty that Russia's victories will be presented by British plans and policies. If Iran is supposed to be on the side of the war, it will surely be Russia (Key, 1976, P. 64-98).

Russia was an emerging power in the European political scene, with its terrible territorial development from the time of Peter the Great, in five stages:

1. Peter's Great Reign on Swedes led to the arrival of the Baltic Sea around 1700 .

2. The Poland was captured by Catherine II (1793-1772).

3. During the two stages in the years 1793 and 1807, the Finns managed to capture Finland.

4. The areas around the Black Sea also captured Russia during a series of battles between 1772 and 1878 with the Ottoman Turks.

5. The advance of the Russians to Asia continued with the seizure of the Caucasus, Central Asia, Siberia and North China, and they led their borders to the Kamchatka Peninsula in the Pacific Ocean. This extraordinary expansion by defeating Iranians, Ottomans and tribes of Central Asia Was obtained (West, 1904, P. 585).

Such a vast empire occupying the largest geographic area of the planet was governed only by autocracy and self-reliance. The tyranny of the Russian Empire with the use of secret soldiers and police and repression and censorship was able to survive the revolutionary tempo of 1848 and even to crush revolu- 
tionary movements in other parts of Europe as a "weapon of despotism stockpile." Russia's defeat in the Crimean War in the hands of the French and British forces revealed the flaws of the Russian regime that was hiding behind the backdrop of authoritarian power, and even showed it to the hard-line Russian conservatives that Russia was hopelessly oppressive Western Europe is backward (Spielvogel , 2002, P.1013).

Russia, which had seized the Black Sea and the Crimea for the rest of the world from 1791, after defeating the Ottomans on the basis of the provisions of the Jyasi Treaty, did not satisfy the achievements of the Black Sea and the Crimea (Saint-Pierre , 1992: 219). They wanted to attach Moldova and Wallachia to their country, but this was the opposition of other European countries, such as the United Kingdom, came to an end, and on January 9, 1792, Russia was forced to abandon the provisions of the Treaty of Yasmine, except for the Crimea and parts of the Black Sea ports (Menzies ,1877,P.238-239). This could not have been the case for an increasingly sought after Russia, an introduction to the Crimean wars in the nineteenth century.

The first deep defeat in the international cooperation system, the achievement of the Vienna Treaties, appeared in the Crimean War (1856-1853); the war broke out on the one hand, the United Kingdom, and the Ottoman, French and Ottoman parties on the other. The Crimean War was an unfortunate and annoying event that nobody wanted, and it also coincided with the collapse of the international cooperation system. The ambitions of Nikolai I (1825-1855) led the Russian tsar to guide him in order to give the Ottomans a privilege in Russia in southern Europe. The Turks, when they were assured of British and French support, stood against Russia's request; at that time, the Ottoman Empire was so weak that it could not afford Russia alone. The British and French sent small troops with help from the Turks and waged more war on the Black Sea Peninsula.

From a military point of view, this war must be a general failure for all parties involved. Russia's command of the Russian forces and its logistics were weaker than the Allies, and after a while, Russia was pushing for disagreement. Peace of 1856 in Paris was a major political breakthrough for St. Petersburg. For the next twenty years, Russia's sentiment has essentially been hampered in southern Europe, and it failed to respond to its longing for a naval base in the Mediterranean.

The Russian military deficiency in Crimea, the new ruler of the country, determined the tsar Alexander II (1881-1855) to address the social and economic problems of Russia, such as the issue of civil war, local governments, the judiciary, and the modernization of the military.

In February 1861, the most detailed order for the release of Serfs, which until then was ordered by the government to abolish the head of state in Russia, was issued. Around 55 million people - Surf and their families - directly affected it. Restoration of the Serfs was only a very limited success. Many of the serfs were unhappy with the land they were assigned to because of its low volume and the quality of the land. But other measures called for major reforms yielded more results. Local governments and the so-called Provincial Commission the Zemstvo Council, as new civil institutions, tried to provide them with the education of farmers to promote their livelihoods. These commissions were the first experience of democracy in Russia.

In 1864, the tsar Alexander issued a decree on the complete reconstruction of the judiciary, and it was not long before Russian courts reached the level of the Western countries. Since then, the class of lawyers and judges who have been involved play an important role in politics.
In 1873, the service of duty, training, and the length of service of the duty system and many other aspects of the Russian military became completely new. The army took on the face of a compulsory institution and became more of an educational and engineering institution, and the government used it to improve the level of education, which was very low in the countryside.

But in the long run, what Alexander did was more important than what he did. He thought, like many of his predecessors, that it was not too long before Russia conquered the Constitution of the Constitutional Monarchy and the National Assembly of the People's Choice or local government committees. Russia remained, like before, a dictatorial state in which only the tsar appointed law and politics.

The lack of interest among farmers in the form of revolutionary reforms has led some revolutionaries to resort to violent means to overthrow tsarist tyranny. One of these fast-paced groups, known as the "will of the people," succeeded in assassinating Alexander II in 1881. The son and his successor, Alexander III (1881-1894), rebelled against the reform, resorting to traditional repressionist methods (Spielvogel , 2002, P.1016).

On the other hand, there was the Ottoman Empire, which was severely confronted with the desires of nationalism of its peoples, especially in the Balkans. The corruption and incompetence of such an Ottoman Empire was undermined by the fact that the only intervention of the great European powers, concerned about each other's plans for seizing the Ottoman lands, was able to keep this empire alive. During the nineteenth century, the Balkan states and the Ottoman Empire gradually gained their independence. By 1829, Serbia had managed to gain a degree of autonomy, but by 1878 it remained a state of the Ottoman Empire. Greece, after its successful uprising of 1830, formed its own independent kingdom. In 1829, Russia, under the Treaty of Adrianople, defamed Moldovan and Wallachian monarchs, but after the Crimean War it was forced to abandon it. Moldova and Wallachia merged in 1861 and created the country of Romania, but the Ottoman Empire did not recognize Romania's independence as well as Serbia's independence until 1878, when it was not defeated by Russia. Montenegro was abandoned from the Ottomans, but fell under the protection of Austria, and Bulgaria, while gaining independence, was under Russian protection, and nationalist forces in the Balkans, in spite of these prosperity, burst out in 1871 . The occurrence of several wars in this region in the early 20th century should be considered as an introduction to World War the first (ibid ,2002,P.1085).

At the same time as the French Revolution and in the era of Sultan Salim III (1808-1789), an attempt was made to reform the financial system and Ottoman troops. The mass murder did not stop the Ottoman reforms, and Mahmoud II reformed the army and moderated the government and the power of religious leaders. Mahmoud's son, following the reform of his father, initiated the era of adjustments in the country. In this period, national schools were formed, and roads and postal services began (1869), but these reforms were not enough to save the imperial (Rossi.E. Don 'et al' , 2003, P.336-339).

\section{A BRIEF REPORT ON THE RUSSIAN-OTTOMAN BATTLE AND THE BERLIN CONGRESS}

Etemad Al-Saltanah begins his reports on how the congress of Berlin was organized, with a brief description of the conflict between Russia and the Ottoman Empire, and writes that on November 10, 1876, the Russian emperor, Alexander II (Empire 18551881), expressed his readiness to fight the country with a claim to support the Ottoman-dominated Christians (Etemad Al-Saltanah, 
1988:1967). At the same time, the Ottoman government was struggling with the rebellion of Bosnia and Herzegovina and laying the rebellion of Bulgaria(ibid,P.1968).at the same time Sultan Abdul Aziz Khan was removed from Caliphate on May 30, 1877 and replaced by Sultan Murad V. This was also one of the other problems of the Ottoman Empire (ibid,P. 1968). These events occurred with the rebellion of Serbia and Montenegro. On August 21- with Claiming of illness and frenzy- in the fatwa of Ottoman Sheikh Al-IslamSultan Murad Khan V was removed from the caliphate, and his younger brother, Abdul Hamid Khan, was appointed to replace him (ibid,P.1969).

The victories of Russia and the Ottoman uprisings led to the convening of a conference by the countries of Austria, Italy, the United Kingdom, France and Germany to solve the Eastern Question in Berlin in 1878(ibid,P.1986). The meeting was attended by representatives of the above-mentioned countries and a representative of the Ottoman Empire and headed by Prince Bismarck. The congress led to the adoption of the Treaty of Berlin (ibid,P. 1987). The Treaty abolishes the a priori compromise between the Ottomans and the Russians, which was concluded at San Stefan (around Istanbul) in the twenty-ninth chapter (ibid,P. 1989). This memorandum has been translated by Etemad Al-Saltanah from Austrian newspapers and the authoritative Ottoman magazine that was called: Waght(Etemad AlSaltanah ,1985,P.1836).

The Treaty of Berlin was concluded in 64 articles, whereby the autonomy of Bulgaria and its borders were recognized, a state was formed in the south of the Balkans, called the Rumlie Sharghi ( Eastern Rumelia ), under the control of the Ottoman Empire, Bosnia and Herzegovina were transferred to the Austrian-Hungarian Empire, independence of Serbia was recognized, the emphasis was placed on protecting the rights and freedoms of the Ottoman non-Muslim citizens, the Ardahan, Kars and Batumi states were transferred to Russia, Russia returned to the Ottomans from the al-Shghaed and Bayazid, which had been seized under the Treaty of San Stefano. The Ottomans returned the city of Qotur and its lands agreed to approve the British and Russian commissars to the Iran (ibid,P.1828-1838). The sixteenth article reiterated: Babe Ali, must give back the city of Qotur and its lands, with the approval of the British and Russian commissars, who were responsible for determining the Ottoman and Iranian boundaries (ibid,P.1836).

\section{THE REASONS FOR THE BEGINNING OF THE WAR}

Etemad Al-Saltanah begins his reports on how the congress of Berlin was organized, with a brief description of the conflict between Russia and the Ottoman Empire, and writes that on November 10, 1876, the Russian emperor, Alexander II (Empire 1855-1881), expressed his readiness to fight the country with a claim to support the Ottoman-dominated Christians (Etemad AlSaltanah, 1988,P.1967).

Alexander II set up a large division for this purpose, and his brother appointed "Nicola" to his command. The profile of the unit was 216,000 pedestrians, 49200 riders, and 648 cannons. 100 million Manats (Russian currency at that time) were paid to cover this department. This money was borrowed from domestic borrowing. He writes that all Russian people from every country and everywhere wrote letters to the Russian emperor and thank him for that he was thinking of the liberation of the Christians under the rule of the Ottoman Empire. The troops of Russia were stationed in the region of the south of the city of Edessa called "Kishien" (ibid,P.1967).
At the same time, the Ottoman government was fighting with the rebels in Bosnia and Herzegovina. The Austrian, Russian, German and British governments supported the insurgents and sent a joint letter to Istanbul asking for the following:

The full freedom of the people and the followers of various religions, the imposition of a fair and taxable tax, the encouragement of farmers and seafarers, the payment of part of the taxes collected from the two states in those regions, the Creating a parliamentary system with the participation of Christians and Muslims in these areas, and the establishment of rules for The welfare and comfort of its inhabitants; but the Ottoman government does not accept these conditions, and only accepts the general tax deductions in these areas (ibid,P.1968-1969).

The Ottomans in Bulgaria, Serbia and Montenegro were also faced with insurrection and independence struggles and at the same time faced with the succession crises of their sultans. On May 30th, Sultan Abdul Aziz Khan was dismissed from the monarchy and Sultan Murad, fifth, sat in place of him, but this was not the end of the story, because on the 21st of August, he was ordered by the decree (fatwa) of the Shaykh al-Islam of the caliphate and his younger brother, Abdul Hamid Khan, was appointed to replace him. The illness and madness of the previous caliph announced (ibid,P. 1969).

The war in Serbia was in the interest of the Ottomans and therefore the Serbs sought help from Russia. A large number of Russian soldiers and volunteers went to Serbia. On December 12, Gen. Ekanatyev, the Russian Ambassador to Ottoman, announced a conference with the presence of representatives of major European states in Istanbul, announcing a new situation as to how the Ottomans were confronted with the function of the Christians. The Ottoman Empire did not accept these conditions, and this made the war more intense (ibid,P. 1969).

\section{START THE WAR}

Immediately after the Ottoman government refused the terms of the conference, the Russian emperor began a war against the Ottoman Empire. The Russian emperor stated this in a letter to Austria, Germany, France and Italy, citing the war as a defense of the rights of Christians living in the Ottoman Empire. The Russian emperor took charge of his army. Russian troops entered the Ottoman Empire and closed the embassies of the two countries at the start of the war (ibid,P. 1974).

Although the Ottoman sheikh al-Islam proclaimed jihad, this did not prevent the Turkish troops from being defeated. By December 10 of that year, the cities of Ardahan, Kars and Plona were occupied by the Russians. The Serb allies also rebelled against the Ottomans (ibid,P.1986).

The Iranian ambassador to France, in his reports, reported on Russia's conquest and occupation of the cities of Kars and Polona and wrote that the Ottoman situation was very turbulent. The ambassador has carefully described the spoils and captives captured by the Russians. He also writes that the governments of England, Nemesis and Italy are working for reconciliation, but will not compromise unless the Russians finish the job. In the ambassador's view, what is facilitating the Russians' progress is the German government's support for them, and although the British appear to support the Ottomans, they will certainly not be willing to kill the British soldiers for the Ottomans. In his view, it is necessary for the Iranian government to appease the Russians, and if the Iranian government is willing to express itself on one side of the war, pro-Russian support is in the best interest of the country and comes with common sense (Key, 1976,P. 63-74). 


\section{BERLIN CONGRESS AND SAN STEFANO TREATY VIOLATION}

Finally, in 1878, with the conclusion of the Congress of Berlin, the final decision was made on the Ottoman-Russian battles and the independence of some Balkan countries and the introduction of a new political order in Europe that era. At the same time, Austrian Chancellor, Kenneth Andersey , declared that he did not accept the terms of the San Stefano Treaty, and that the Austrian troops immediately seized Bosnia and Herzegovina. But in the newly-founded German state, the emperor declared that he would do his best to reach a compromise between the Russians and the Ottomans and maintain peace in all European states (Etemad Al-Saltanah, 1988,P.1987).

The Congress of Berlin was chaired by Prince Bismarck. Representatives of countries: Germany, Austria, France, England, Italy, Russia and the Ottomans attended the congress. After lengthy discussions, the provisions of the Berlin Treaty were adopted. With the annulment of the San Stefano treaty, the Ottomans achieved better conditions in the new treaty. Britain's dissatisfaction with Russian military advances within the European continent - which had failed to lead to a military conflict between Russia and Britain - was one of the main reasons for the cancellation of the San Stefano Treaty. The Ottoman government took full advantage of this situation and conferred on Cyprus a secret treaty to thank Britain. Thus Russia, which had succeeded in conquering large areas of the Ottoman Empire during its battles, would have to replace its vast gains in the San Stefano Treaty with few concessions to the provisions of the Congress of Berlin. Once again, as in the Crimean wars, it was the coordination of Western European countries that kept Russia from achieving its goals. Russia, which had conquered Batumi, Erzurum Elrom, Serbia, Montenegro, Romania and Sofia during hese battles, had gained additional points during the 29 chapters

\section{Reference list:}

1. Etemad Al-Saltanah, Mohammad Hassan Khan. (1985) Merat alBoldanand.1th edn.Tehran: Tehran University Press. (Correction and research: Abdolhoseyn Nawaee and Mir Hashem Mohaddes).

2. Etemad Al-Saltanah,Mohammad Hassan Khan.(1988)Montazame Nasseri's History 1th edn.Tehran: Donyaye Ketab Press. (Correction and research: Mohammad esmaeil Rezwani)

3. Key , Mahmud. (1976 ) Letters from the Iranian Ambassador to France to the Foreign Minister of Iran under Nassereddin Shah Qajar. 1th edn.Tehran: Historical Reviews (Number One, Tenth Year 1355).

4. Menzies, Sutherland.(1877) History of the Ottoman Empire in Europe. 1th edn. London and Glasgow: William Collins and Company.

5. Rossi.E. Don and others.(2003) The history of civilization and culture of the world, translation of Abdul Hussein Azarang. 1th edn. Tehran: Tarheno Publishing House.

6. Saint-Pierre, Michel de.(1992). Romanov Tragedy, Translated by Mitra Masoumi. 1th edn. Tehran: Roshangaran Publishing House.

7. Spielvogel, Jackson Joseph.(2002) Western Civilization, Translated by Mohammad Hossein Aria. 1th edn. Tehran: Amir Kabir Publications.

8. West, Willis Mason.(1904) Modern history; Europe. 1th edn Boston: Allyn and Bacon. of the San Stefano Treaty, including war compensation of 2820 crores Manat (equal to 1,410 million manat) is mentioned by the Ottomans. In the same treaty, Bulgaria, Kars and Ardahan were annexed to the Russian Empire (ibid,P. 1988-1989).

The Congress of Berlin eliminated most of Russia's concessions and the Bayezid state, and one-third of Bulgaria, which had been exempted from the Ottoman territory by the Treaty of San Stefan, returned to the state and was released from the Black Sea for all public officials (ibid,P.1990).

\section{RESULTS}

Although unilateral military action by the Russians and acceptance of the casualties and costs of the war resulted in military successes, its achievements were lost by the annulment of the San Stefano Treaty and the adoption of the Berlin Congress. Russia, which had begun these wars under the pretext of protecting the Christian nations under Ottoman rule, could not achieve its goals. Britain and Germany, with the help of Austria, laid out a new order for Europe. Austria was able to conquer Bosnia and Herzegovina. The main losers were the Ottomans and then Russia. The British succeeded in conquering Cyprus by preventing Russian expansion into Europe by displaying support for the Ottomans and, indeed, feeling threatened by the Russians' advance to the continent. The Germans, who were celebrating the founding of their country at the same time, have since emerged as a new force in supplying European political equations. NonMuslim nations under the Ottoman Empire, gained relative autonomy and independence, and the Mediterranean and the Bosporus and the Dardanelles were recognized as free trade channels. This war made the necessity of reform in Russia and the Ottoman countries more clear, and modern Iranian historiography sought to understand the manifestations of modern world order and European diplomacy.

Статья проверена программой «Антиплагиат».

\section{Список литературы:}

1. Etemad Al-Saltanah, Мохаммад Хассан Хан. (1985) Мерат альБолдан и 1-е изд. Тегеран: издательство Тегеранского университета (исправление и исследование: Абдолхосейн Навайи и Мир Ашем Мохаддес)

2. Etemad Al-Saltanah, Мохаммад Хассан Хан. (1988) История MontazameNasseri 1-е изд. Тегеран: DonyayeKetabPress. (Исправление и исследование: Мохаммад Эсмаил Резвани)

3. Ки, Махмуд. (1976) Письма посла Ирана во Франции министру иностранных дел Ирана при Насеререде Шахе Каджар. 1-е издание. Тегеран: Исторические обзоры (номер один, десятый год 1355).

4. Мензис, Сазерленд. (1877) История Османской империи в Европе. 1-е изд. Лондон и Глазго: Уильям Коллинз и Компания.

5. Rossi.E. Дон и др. (2003) История цивилизации и мировой культуры, перевод Абдул-Хуссейна Азаранг. 1-е изд. Тегеран: Тархено, Издательский Дом.

6. Сен-Пьер, Мишель де. (1992). Трагедия Романова, перевод Митра Масуми. 1-е изд. Тегеран: Издательство Рошангаран.

7. Spielvogel, Джексон Джозеф. (2002) Западная цивилизация, перевод Мухаммеда Хоссейна Ария. 1-е изд. Тегеран: Амир Кабир Публикации.

8. Запад, Уиллис Мейсон. (1904) Современная история; Europe.1th edn. Бостон: Аллин и Бэкон. 


\section{ОТ РЕДКОЛЛЕГИИ РЕКОМЕНДУЕТ СТАТЬЮ ДЛЯ ПУБЛИКАЦИИ}

Йешилбурса Бехчет Кемаль (Турция) - доктор исторических наук, профессор истории, Улудагский университет, исторический факультет (г. Бурса, Турция)

РЕЦЕНЗИЯ

на статью Мохаммада Салмасизаде «Русско-турецкая война 1877-1878 гr. в иранской историографии XIX в. и в современной иранской историографии»

Проблематика истории внешней политики России на Востоке относится к числу весьма актуальных тем в современной историографии. В условиях «разворота России на Восток», связанного с событиями 2014 г. на Украине, весьма важным является использование исторического опыта, изучение того, как воспринималась и воспринимается Россия в различных странах Азии. Между тем, российское академическое сообщество пока еще весьма слабо осведомлено о тех подходах, которые существуют в национальных историографиях стран региона. Именно в этом актуальность исследования, предпринятого иранским историком Мохаммадом Салмасизаде.

Основное внимание М. Салмасизаде сосредоточено на осуществлении Российской империей внешней политики на Ближнем и Среднем Востоке в XIX в. В центре внимания - фигура Э. Эль-Салтана, одного из первых иранских просветителей, известного историка эпохи шаха Насреддина (вторая половина XIX в.). Э. Эль-Салтана известен тем, что первым в иранской историографии использовал принципы критического подхода к историческим источникам.

\section{INFORMATION ABOUT THE AUTHOR}

Mohammad Salmasizadeh, Dr. Sci. (Hist.), associate professor; Scientific Advisor, University Of Tabriz, Faculty of Law and Social Sciences. Department of History, Tabriz, Iran, http://orcid.org/identifier is 0000-0002-8613 1321, e-mail: msalmasizadeh@tabrizu.ac.ir
Автор статьи знакомит читателей с взглядами Э. Эль-Салтана на внешнюю политику России в XIX в. и ее отношения с Западом. Особое внимание в статье уделено роли Крымской войны в процессе трансформации системы международных отношений. М. Салмасизаде показывает, что Э. Эль-Салтана уделял внимание и внутренним процессам в развитии России эпохи Александра II, значению отмены крепостного права, специфике политического режима в России.

Значительное место в статье М. Салмасизаде занимает подробный анализ решений Берлинского конгресса 1878 г., влиянию этого международного форума на расстановку сил в Европе в конце XIX в.

В целом статья Мохаммада Салмасизаде соответствует предъявляемым требованиям и может быть рекомендована к публикации в журнале «История и современное мировоззрение».

доктор исторических наук, доцент, профессор кафедры востоковедения Уральского федерального университета им. первого Президента России Б. Н. Ельцина

А. В. Антошин

\section{ИНФОРМАЦИЯ ОБ АВТОРЕ}

Салмасизаде Мохаммад, доктор исторических наук, доцент, научный консультант, Факультет права и общественных наук, исторический факультет, Университет Тебриза, Тебриз, Иран, http://orcid.org/identifier is 0000-0002-8613-1321, e-mail: msalmasizadeh@tabrizu.ac.ir 